\title{
Chapter 31 \\ Article 37: Prohibition of Torture, Capital \\ Punishment, and Arbitrary Deprivation of Liberty
}

\author{
Christian Whalen
}

States Parties shall ensure that:

(a) No child shall be subjected to torture or other cruel, inhuman or degrading treatment or punishment. Neither capital punishment nor life imprisonment without possibility of release shall be imposed for offences committed by persons below 18 years of age;

(b) No child shall be deprived of his or her liberty unlawfully or arbitrarily. The arrest, detention or imprisonment of a child shall be in conformity with the law and shall be used only as a measure of last resort and for the shortest appropriate period of time;

(c) Every child deprived of liberty shall be treated with humanity and respect for the inherent dignity of the human person, and in a manner which takes into account the needs of persons of his or her age. In particular, every child deprived of liberty shall be separated from adults unless it is considered in the child's best interest not to do so and shall have the right to maintain contact with his or her family through correspondence and visits, save in exceptional circumstances;

(continued)

C. Whalen (ه)

Office of the Child, Youth and Seniors Advocate, Fredericton, NB, Canada

e-mail: Christian.Whalen@gnb.ca 
(d) Every child deprived of his or her liberty shall have the right to prompt access to legal and other appropriate assistance, as well as the right to challenge the legality of the deprivation of his or her liberty before a court or other competent, independent and impartial authority, and to a prompt decision on any such action.

\section{What Did Children Say?}

Does anyone go where accused or convicted children stay to 'ask questions and verify the truth?' The person would work in the prison. (Western Europel Other)

Government should build places where not only children can be imprisoned but also an institution where they can learn trade and educate them about the negativity of committing crimes at an early age. (Africa)

Train enough guards, police officers, chiefdom officers, more youths, and school authorities and bordering community people to make sure that any child labour, illegal movement of persons, and criminal issues against girls should be reported. (Africa)

\section{Overview}

Articles 37 and 40 share a common genesis in the several rounds of working sessions leading to the adoption of the Convention. The debate and work on these articles was sustained and intense. It occurred at a time when international norms for juvenile justice were rapidly evolving. States Parties were significantly divided on the wording of the juvenile justice provision, and after several drafts, suggested edits by the UN Office's Centre for Social Development and Humanitarian Affairs gave a new direction (S. Detrick et al., 1992, pp. 458-478). Following much debate, the provision was divided into two separate articles. The first one, which became Article 37 , dealt with the prohibition of torture and cruel treatment, capital punishment and deprivation of liberty. The second article, which became Article 40, set out the minimum standards of fairness for criminal trials involving minors.

In both instances, emphasis on the child's human dignity, and the rehabilitation and reintegration of youth, are paramount concerns. The articles were drafted with close attention to emerging global standards in the area and with existing human rights treaty provisions (S. Detrick et al., 1992, pp. 458-478). ${ }^{1}$ In its final wording, it is evident that a large part of the text of Article 37 is inspired by Articles 6 (5), 7, 9, and 10 of the International Covenant on Civil and Political Rights (ICCPR).

\footnotetext{
${ }^{1}$ See also Ton Liefaard, Juvenile Justice and Children's Rights (Liefaard, 2015, pp. 252-254).
} 
However, without duplicating the wording of the ICCPR, Article 37 extends the ICCPR's provisions to the protection of the children by:

- Imposing the prohibition of life imprisonment for children without the possibility of release

- Demanding that detention of a child shall be used as a measure of last resort and be imposed for the shortest period of time

- Providing to children deprived of their liberty the rights to maintain contacts with their family members (Tobin and Hobbs, 2019, p. 1421).

As underlined by the Committee, Article 37 imposes a child-centred understanding of its provisions and rights (Tobin and Hobbs, 2019, p. 1422). This clarified that the rights recognised by Article 37 extend beyond the ambit of child justice administration to all situations where children may be deprived of liberty, including, for example, child protection settings, health care settings, and immigration settings.

Article 37 can be analysed succinctly in accordance with its four constituent paragraphs:

- The prohibition in paragraph (a) on torture or ill-treatment, specifically ruling out capital punishment and life imprisonment without parole for minors

- The prohibition in paragraph (b) of unlawful and arbitrary deprivations of liberty, insisting that such sanctions are a measure of last resort that must only be imposed for the shortest appropriate period

- Limitations on the deprivation of liberty, including the core commitment in paragraph (c) to upholding the child's inherent dignity and right to be treated with humanity in such circumstances

- The Article establishes, in paragraph (d), the minimal due process guarantees which must accompany any child's deprivation of liberty.

While youth criminal justice practice varies greatly from state to state, Articles 37 and 40 have emerged as a codification of global standards set out in the Beijing Rules and a summary prompt to the adoption of guidelines and minimum rules for the protection of children deprived of liberty and the prevention of youth crime (Vučković-Šahović et al., 2012, p. 298). Article 37 should therefore be applied consistently with the recent General Comment no. 24 (2019) on Children's Rights in the Child Justice System.

\section{General Principles}

Article 2 Children deprived of liberty are a vulnerable sector of the youth population, much in need of non-discrimination and equality protections, within the meaning of 'other status' in Article 2. At the same time minority, indigenous, disabled, LBGTQ+ youth, and other vulnerable youth populations are particularly at risk of marginalisation and criminalisation. They are also more likely to be 
deprived of liberty in non-correctional settings, including health care, immigration detention, and child protection settings (Nowak, 2019, paras. 30-34).

Article 3 There is an inherent contradiction between the best interests principle and the cautioning of child imprisonment in Article 37 (Liefaard, 2015, para. 252). Goldson and Kilkelly maintain that the practical realities of child imprisonment are so pervasively detrimental to human development that even the best efforts at penal reform cannot escape the categorisation that child imprisonment results in the deliberate imposition of 'organized hurt' (Goldson and Kilkelly, 2013, p. 370). State interests will bend understandably towards a minimum threshold of repressive penal sanction, even regarding children in exigent circumstances, but the best interest principles will invariably support Article 37's insistence on recourse to imprisonment as a last resort and for the shortest reasonable time. Best interests analysis will also support Article 37's emphasis on separation of youth and adult prisoners, maintenance of family contact, prohibition of solitary confinement, and of certain measures of restraint; it will support access to education, sanitary conditions, clothing, healthy nutrition, rest, and physical activity during detention.

Article 6 Article 6 is the General Principle most closely linked with Article 37, since the guarantee of the right to life is echoed in Article 37's prohibition on imposition of the death penalty. Survival and maximum development of the child provide a counterpoint to the prohibition of life imprisonment, torture, or cruel or degrading punishment. Moreover, the guarantee of the right to life in human rights instruments is typically combined with the right to liberty and security of the person, ${ }^{2}$ foundational rights that lie at the heart of the child's evolving path towards autonomy and their right to survival and development. This stands as a positive formulation of the child's liberty interests, as protected in the prohibition against unlawful and arbitrary detention of children. There are very few situations of possible Article 37 infringements where Article 6 would not also be in play.

Article 12 The child's right to be heard and to have their opinions considered is never so clearly manifest as when a deprivation of liberty may be imposed, and yet child participation rights in detention proceedings are often compromised. Article 12 includes the child's right to complaint mechanisms within institutions and the right to be informed of all institutional rules to which they may be subject and of existing procedures for redress (UNICEF, 2007, p. 566; UN Committee on the Rights of the Child, 2007a, para. 28).

\footnotetext{
${ }^{2}$ See, for example, Article 3 of the UDHR's proclamation 'Everyone has the right to life, liberty and security of the person', a formulation repeated verbatim as section 7 of the Canadian Charter of Rights and Freedoms and inspired by the American Declaration of Independence's assertion of the rights to 'life, liberty and the pursuit of happiness'.
} 


\section{Articles Related or Linked to Article 37}

Article 9 provides for the child's right to not be separated from their parents unless it is necessary in the child's best interests, as determined by competent authorities, which may occur where cruel and degrading treatment of children occurs within the family home.

Article 16 addresses the child's right to privacy and the inviolability of their family life and against affronts to honour and reputation. Cases of egregious bullying may infringe both Articles 16 and 37.

Article 19 establishes the child's right to be free from all forms of violence, abuse, neglect, and maltreatment and thus intersects closely with the protections in Article 37.

Article 20 provides for the child's right to alternative care if deprived of his or her family, as may occur if the child was a victim of cruelty at home.

Article 22 notes the rights of refugee children to special protection and access to their rights, and intersects with Article 37 when children are deprived of liberty in immigration detention centres or treated cruelly or in a degrading manner through the immigration process.

Article 24 addresses the child's right to the highest attainable standard of health and to access health care services, and these rights are vitally in play for every child victim of a violation of Article 37 rights.

Article 25 provides the right to periodic review of placement or treatment, notably with a view to guard against cruel or inhuman treatment in such placements.

Article 34 states the child's right to be protected from sexual exploitation, which may occur while in detention and which invariably may raise questions regarding possible violations of Article 37.

Article 35 addresses the child's right to be protected from abduction, sale, or trafficking, any one which may be characterised as cruel, degrading, or inhuman.

Article 38 covers prohibition of forced enrolment in armed conflicts, another express form of cruel and degrading treatment of children.

Article 39 provides for the right to recovery and reintegration for child victims of neglect, exploitation, abuse, torture, cruel treatment, or armed conflict, such that all violations of Article 37 should be scrutinised for applicable Article 39 rights.

Article 40 provides for the right to a separate system of youth criminal justice.

Optional Protocol on the sale of children, child prostitution and child pornography.

Optional Protocol on the involvement of children in armed conflict.

\section{Relevant Instruments}

UN Convention Relating to the Status of Refugees (1951) 
International Covenant on Civil and Political Rights (1966), Articles 6, 7, 9 , and 10

UN Convention against Torture and Other Cruel, Inhuman or Degrading Treatment or Punishment (1984)

UN Standard Minimum Rules for the Administration of Juvenile Justice (Beijing Rules) (1985)

UN Rules for the Protection of Juveniles Deprived of their Liberty (Havana Rules) (1990)

UN Guidelines for the Prevention of Juvenile Delinquency (Riyadh Guidelines) (1990)

Geneva convention for the amelioration of the condition of the wounded and sick in armed forces in the field (1949), and their Protocols I and II

European Convention on Human Rights (1950), Articles 3 and 5

African Charter on Human and Peoples' Rights (1981), Articles 4, 5, and 6

African Charter on the Rights and Welfare of the Child (1990), Articles 16 and 17

\section{Attributes}

\section{Attribute One: Prohibition of Capital Punishment, Life Imprisonment, Torture or Degrading Treatment}

The first attribute repeats for children the general human right provision on the prohibition of torture or other cruel or inhuman or degrading treatment or punishment, but it immediately expands this right with explicit prohibitions of capital punishment and life imprisonment without parole for offences committed by children. While the Convention contemplates the possibility of life imprisonment for a child, the Committee does not, arguing that life imprisonment, even with the possibility of parole, would defeat the rehabilitative aims of juvenile justice (2007a, para. 77). The Committee recommends that all States Parties abandon recourse to life imprisonment for any offence by minors (2007a, para. 77).

With reference to the prohibition of cruel, inhuman, or degrading treatment or punishment, the Committee has never provided a list of prohibited acts or clarification of the distinction between the different kind of punishments or treatments. Therefore, a case by case assessment is required to determine the nature, purpose and severity of the treatment imposed (Tobin and Hobbs, 2019, p. 1439). The prohibition imposed by Article 37 is absolute and non-derogable. Furthermore, based on the General Comment no. 8, it extends to encompass any use of corporal punishment as a penal or administrative sanction (UN Committee on the Rights of the Child, 2007a, para. 71, 2007b, paras. 2, 16, 18). In addition, the Committee, in its concluding observation to States Parties' reports, has categorised as torture, amputations and mutilations against children (2000, paras. 44, 45), sexual assaults in 
conflict zones (2006a, paras. 50, 51) and solitary confinement of children (2005, para. 59, 2007a, para. 89).

\section{Attribute Two: Principle of Non-detention of Children, and If Necessary, Only as Last Resort and for the Shortest Appropriate Time}

Paragraph 37 (b) sets out the principle of non-detention of children. It repeats the general human rights criterion that there can be no arbitrary or unlawful deprivation of liberty but illustrates it with the new rule that children under 18 can only be deprived of liberty as a measure of last resort and for the shortest appropriate time. In practice, this requires use of alternative sanction measures, such as probation, community service, and suspended sentences (UN Committee on the Rights of the Child, 2006b, para. 62 (d)). In General Comment no. 24, the Committee recommends that pre-trial detention must be limited to the greatest extent possible from the moment of arrest forward and that its duration should also be limited in law and subject to regular review (2019, paras. 8, 82-95).

\section{Attribute Three: Humane Treatment and Respect for Human Dignity at All Times}

General Comment no. 24 reinforces the language of Article 37 (c) and sets out human dignity as the foundational human rights value underpinning the protection of liberty in Article 37. This attribute serves to remind all duty-bearers that young persons accused of crimes are children first. The purpose of youth criminal justice is to rehabilitate and reintegrate the youth offender. Owing to their stage of development, youth have not the moral blameworthiness or the mental capacity to be held to account for their behaviour the way adults should be. Separation from adults and contact with family are two indicators that will exemplify this criterion of humanity and human dignity. But the requirements are far-reaching. Detained children are not deprived of their other rights under the Convention, and their educational, social, psychological, and spiritual development must continue, and centres of detention must provide this in an adapted child-friendly setting (Liefaard, 2015, p. 254; UN Committee on the Rights of the Child, 2007a, paras. 88-89; UN General Assembly, 1985, Rule 10.3). 


\section{Attribute Four: No Deprivation of Liberty Without Due Process}

Most of the fairness requirements upon arrest are set out in Article 40, but Article 37 (d) sets out minimal requirements that are applicable in all deprivations of liberty, whether in the penal law context or in health, immigration, or other administrative contexts. Prompt access to legal and other assistance, including interpretation and counselling services as required, must be provided. The mechanisms for review must be explained and made promptly available as well, normally within $24 \mathrm{~h}$ (UNICEF, 2007, p. 565; UN Committee on the Rights of the Child, 2007a, para. 28 (a)).

Prompt and easy access to child sensitive complaints mechanisms must be provided to children, who should be informed of the response without delay (UN Committee on the Rights of the Child, 2007a, para. 28 (c)). Training in child rights principles should be provided to all court officials, policing and correctional officials, and other institutional staff involved with children under detention (UNICEF, 2007, pp. 566-567).

\section{References}

Detrick, S., Doek, J. E., \& Cantwell, N. (1992). The United Nations convention on the rights of the child: A guide to the "Travaux Préparatoires." Martinus Nijhoff Publishers.

Goldson, B., \& Kilkelly, U. (2013). International human rights standards and child imprisonment: Potentialities and limitations. The International Journal of Children's Rights, 21(2), 345-371. https://doi.org/10.1163/15718182-55680011

Liefaard, T. (2015). Juvenile justice and children's rights. In Routledge international handbook of children's rights studies (pp. 234-256). Routledge.

Nowak, M. (2019). Global study on children deprived of liberty, A/74/136. UN. Accessed November 22, 2020, from http://digitallibrary.un.org/record/3813850

Tobin, J., \& Hobbs, H. (2019). Article 37: Protection against torture, capital punishment, and arbitrary deprivation of liberty. In J. Tobin (Ed.), The UN convention on the rights of the child: A commentary (pp. 1420-1502). Oxford University Press.

UN Committee on the Rights of the Child. (2000). Concluding observations: Sierra Leone, February 24, 2000, CRC/C/15/Add.116. UN. Accessed November 22, 2020, from http:// digitallibrary.un.org/record/414185

UN Committee on the Rights of the Child. (2005). Concluding observations: Denmark, November 23, 2005, CRC/C/DNK/CO/3. UN. Accessed November 22, 2020, from http://digitallibrary.un. org/record $/ 569980$

UN Committee on the Rights of the Child. (2006a). Concluding observations: Colombia, June 8, 2006, CRC/C/COL/CO/3. UN. Accessed November 15, 2020, from http://digitallibrary.un. org/record/582283

UN Committee on the Rights of the Child. (2006b). Concluding observations: Latvia, June 28, 2006, CRC/C/LVA/CO/2. UN. Accessed November 22, 2020, from http://digitallibrary.un. org/record/580091

UN Committee on the Rights of the Child. (2007a). General comment no. 10 (2007) Children's rights in juvenile justice, April 25, 2007, CRC/C/GC/10. Accessed October 12, 2020, from https://digitallibrary.un.org/record/599395? $\mathrm{ln}=\mathrm{en}$

UN Committee on the Rights of the Child. (2007b). General comment no. 8 (2006) The right of the child to protection from corporal punishment and other cruel or degrading forms of punishment 
(arts. 19; 28, para. 2; and 37, inter alia), March 2, 2007, CRC/C/GC/8. Accessed October 12, 2020, from https://digitallibrary.un.org/record/583961? $\ln =\mathrm{en}$

UN Committee on the Rights of the Child. (2019). General comment no. 24 (2019) on children's rights in the child justice system, CRC/C/GC/24. Accessed November 29, 2020, from https:// tbinternet.ohchr.org/_layouts/15/treatybodyexternal/Download.aspx?symbolno=CRC\%2fC $\%$ $2 \mathrm{fGC} \% 2 \mathrm{f} 24 \&$ Lang $=\mathrm{en}$

UN General Assembly. (1985). United Nations standard minimum rules for the administration of Juvenile Justice ("The Beijing Rules"), 1985, A/RES/40/33. Accessed November 6, 2020, from http://digitallibrary.un.org/record/120958

UNICEF. (2007). Implementation handbook for the convention on the rights of the child (3rd ed.). UNICEF. Accessed September 21, 2020, from https://digitallibrary.un.org/record/620060? $\ln =\mathrm{en}$

Vučković-Šahović, N., Doek, J. E., \& Zermatten, J. (2012). The rights of the child in international law: Rights of the child in a nutshell and in context: All about children's rights. Stämpfli.

Open Access This chapter is licensed under the terms of the Creative Commons Attribution 4.0 International License (http://creativecommons.org/licenses/by/4.0/), which permits use, sharing, adaptation, distribution and reproduction in any medium or format, as long as you give appropriate credit to the original author(s) and the source, provide a link to the Creative Commons license and indicate if changes were made.

The images or other third party material in this chapter are included in the chapter's Creative Commons license, unless indicated otherwise in a credit line to the material. If material is not included in the chapter's Creative Commons license and your intended use is not permitted by statutory regulation or exceeds the permitted use, you will need to obtain permission directly from the copyright holder.

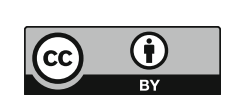

